\title{
Clinical Relevance of Preoperative Neutrophil to Lymphocyte and Platelet to Lymphocyte Ratio in Renal Cell Carcinoma
}

\section{Renal Hücreli Karsinomda Preoperatif Nötrofil/Lenfosit ve Trombosit/Lenfosit Oranının Klinik Önemi}

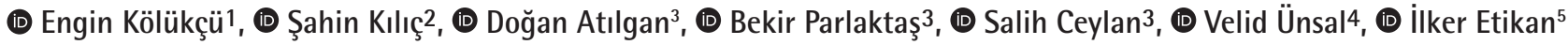 \\ ${ }^{1}$ Tokat State Hospital, Clinic of Urology, Tokat, Turkiye \\ 2 Fethiye State Hospital, Clinic of Urology, Muğla, Turkiye \\ ${ }^{3}$ Gaziosmanpaşa University Faculty of Medicine, Department of Urology, Tokat, Turkiye \\ ${ }^{4}$ Mardin Artuklu University, High School of Health and Central Research Laboratory, Mardin, Turkiye \\ ${ }^{5}$ Near East University Faculty of Medicine, Department of Biostatistics, Lefkoşa, Northern Cyprus
}

\begin{abstract}
What's known on the subject? and What does the study add?
Systemic inflammatory reactions cause alterations in full blood count parameters; with a particular decline in the lymphocyte count, and neutrophil and platelet count increments. Both neutrophil-to-lymphocyte ratio and platelet-to-lymphocyte ratio are reproducible, simple and low-cost parameters highly effective in reflecting the inflammatory response. Recent analyses provide evidence that assessment of preoperative systemic inflammatory response contributes to prediction of stage-free cancer survival. Although not statistically significant, a positive correlation was observed between high tumor and nuclear grades and tumor-to-liver uptake ratio and platelet-to-lymphocyte ratio. It is concluded that, multi-center and prospective studies with more patients is needed for the achievement of meaningful results.
\end{abstract}

\begin{abstract}
Objective: The association of preoperative neutrophil-to-lymphocyte ratio (NLR) and platelet-to-lymphocyte ratio (PLR) with postoperative tumor stage and Fuhrman nuclear grade was investigated in patients with renal cell carcinoma (RCC).

Materials and Methods: Data of 123 patients, who were operated due to RCC, in our clinic was analysed. NLR and PLR were evaluated in patients who were classified according to tumor stage (T1 and T2 low stage, T3 and T4 high stage) and Fuhrman nuclear grade (grade 1 and 2 low-grade, grade 3 and 4 high-grade). NLR and PLR were compared using Levene's test between the groups.

Results: Sixty four patients were female (52.1\%) and 59 were male (47.9\%). All haematological parameters were expressed as $10^{3} / \mu \mathrm{L}$. Mean age, blood neutrophil, lymphocyte and platelet counts, and NLR and PLR values of the patients were $62.49 \pm 12.43$ years, 6.27 $\pm 2.8,2.05 \pm 0.83$, $263.72 \pm 89.03,4.01 \pm 3.93$, and $149.73 \pm 82.1$, respectively. The most common histologic subtype was recorded as clear cell RCC (76.4\%). NLR and PLR were $3.83 \pm 3.22$ and $142.79 \pm 66.66$, respectively in the low-stage group and $4.43 \pm 5.29$ and $165.85 \pm 109.41$, respectively in the high stage group. As for the Fuhrman nuclear grading, NLR and PLR were $3.81 \pm 3.45$ and $146.63 \pm 87.36$, respectively in the low-grade group and $4.61 \pm 5.387$ and $159.32 \pm 63.42$ in the high-grade group. There was no statistically significant difference between the groups ( $p>0.05)$.

Conclusion: Although not statistically significant, high tumor stage and nuclear grade were positively correlated with NLR and PLR. It is concluded that, further multi-center and prospective studies with larger samples are needed to derive meaningful results.
\end{abstract}

Keywords: Lymphocyte, Neutrophil, Platelet, Renal cell carcinoma

Öz

Amaç: Bu çalışmada renal hücreli karsinomlu (RHK) hastalarda operasyon öncesi nötrofil/lenfosit oranı (NLO) ve trombosit/lenfosit oranın (TLO), postoperatif tümör evresi ve Fuhrman nükleer derecesinin ilişkisi incelenmiştir.

Correspondence: Engin Kölükçü MD, Tokat State Hospital, Clinic of Urology, Tokat, Turkiye

E-mail: drenginkolukcu@gmail.com ORCID-ID: orcid.org/0000-0003-3387-4428

Received: 12.06.2018 Accepted: 24.06.2018

Cite this article as: Kölükçü E, Kılıç Ş, Atılgan D, Parlaktaş B, Ceylan S, Ünsal V, Etikan i. Clinical Relevance of Preoperative Neutrophil to Lymphocyte and Platelet to Lymphocyte Ratio in Renal Cell Carcinoma. J Urol Surg 2018;5(4):189-193.

๑Copyright 2018 by the Association of Urological Surgery / Journal of Urological Surgery published by Galenos Publishing House. 
Gereç ve Yöntem: Kliniğimizde RHK nedeniyle opere edilen 123 hastanın verileri geriye dönük olarak incelendi. Tüm hastaların patolojik evreleri, histolojik tümör tipleri ve dereceleri, preoperatif tam kan sayımları değerlendirilerek kayıt edildi. Hastalar tümör evrelerine (T1 ve T2 hastalar düşük evreli, T3 ve T4 hastalar yüksek evreli) ve Fuhrman nükleer derecelerine (grade 1 ve 2 hastalar düşük dereceli, grade 3 ve 4 hastalar yüksek dereceli) göre sınıflandırılarak NLO ve TLO değerlendirildi. Levene testi kullanılarak grupların NLO ve TLO'su istatistiksel olarak karşılaştırıldı.

Bulgular: Hastaların 64'ü kadın $(\% 52,1)$ ve 59'u erkek $(\% 47,9)$ idi. Tüm hematolojik parametreler $10^{3} / \mu \mathrm{L}$ olarak ifade edildi. Hastaların ortalama yaşları, ortalama kan nötrofil, lenfosit, trombosit sayıları, NLO ve TLO'su sırasıyla $62,49 \pm 12,43$ yıl, 6,7 $\pm 2,8,2,05 \pm 0,83,263,72 \pm 89,03,4,01 \pm 3,93$ ve $149,73 \pm 82,1$ idi. En sık izlenen histolojik alt tip berrak hücreli RHK $(\% 76,4)$ olarak kayıt edildi. Düşük tümör evreli grupta NLO ve TLO sırasıyla $3,83 \pm 3,22$ ve $142,79 \pm 66,66$ olarak ölçülürken yüksek evreli grupta $4,43 \pm 5,29$ ve $165,85 \pm 109,41$ olarak değerlendirildi. Düşük Fuhrman nükleer

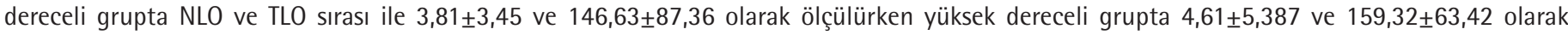
değerlendirildi. Gruplar arasında istatistiksel olarak anlamlı farklılık izlenmedi $(p>0,05)$.

Sonuç: İstatistiksel olarak anlamlı olmasa da yüksek tümör evresi ve nükleer derecesi ile TLO ve NLO arasında pozitif korelasyon olduğu görüldü. Anlamlı sonuçlara ulaşılması açısından daha fazla hasta sayılı, çok merkezli ve prospektif verilere ihtiyaç olduğu sonucuna varıldı.

Anahtar Kelimeler: Lenfosit, Nötrofil, Trombosit, Renal hücreli karsinom

\section{Introduction}

Among urogenital cancers, renal cancers are the third most common malignancies after prostate and bladder cancers (1). Renal cell carcinoma (RCC) is responsible for $80-85 \%$ of all primary renal neoplasms and constitutes $3 \%$ of all adult malignancies (2). RCC is one of the most lethal of the urogenital cancers (3). They are most prevalent in the $5^{\text {th }}$ and $6^{\text {th }}$ decades of life. The male-to-female ratio is $3 / 2$ (4). RCC incidence has been shown to correlate with the level of development of a country (5). RCC has become more prevalent due to technological advancements in radiological imaging modalities and their introduction into clinical practice (6). RCC incidence has been reported to increase by $2-4 \%$ globally in the last decade (7).

Cancer is a multifactorial disease emerging with complex interactions between various environmental factors and genetic variants (8). The microenvironment of tumor formation and inflammatory reactions are associated with tumor development and progression (9). Systemic inflammatory reactions are held responsible for many cancer-related symptoms including anorexia, pain and cachexia as well as shorter life expectancy (10).

Systemic inflammatory reactions cause alterations in full blood count parameters with a particular decline in the lymphocyte count, and neutrophil and platelet count increments (11). Both neutrophil-to-lymphocyte ratio (NLR) and platelet-tolymphocyte ratio (PLR) are reproducible, simple and lowcost parameters highly effective in reflecting inflammatory response. Recent analyses provide evidence that assessment of preoperative systemic inflammatory response contributes to prediction of stage-free cancer survival (12).

This retrospective study investigates the association of preoperative NLR and PLR values with tumor and Fuhrman nuclear stage in patients who underwent radical or partial nephrectomy and received the diagnosis of RCC based on the pathological investigation of the surgical specimens.

\section{Materials and Methods}

Record of patients who underwent radical or partial nephrectomy in the Urology Clinic at Gaziosmanpaşa University Faculty of Medicine between 2011 and 2017 were analyzed retrospectively. A hundred twenty three patients, who received the diagnosis of RCC based on pathological investigation of the surgical specimens, were included in the study. The patients provided informed consent for use of their personal data in scientific studies. The study was conducted in compliance with ethical principles of the Helsinki Declaration. Age, clinical presentation, preoperative hemogram parameters and postoperative pathology results of patients were analysed. NLR and PLR were calculated for each patient after obtaining full blood counts preoperatively. NLR was obtained by dividing neutrophil count by lymphocyte count, whereas PLR was obtained by dividing platelet count by lymphocyte count. All surgical samples were staged according to the 2009 TNM classification (13). T1 and T2 patients were categorized as low-stage and T3 and T4 patients as high-stage. Then, pathology samples were assessed for tumor grades using the Fuhrman system (14). Grade 1 and 2 patients were classified as low-grade, and grade 3 and 4 patients as high-grade. Histological subtypes were evaluated according to the classification defined by the World Health Organization (15). Cut off values were set for tumor-to-liver uptake ratio and PLR as 2.61 and 128.75, respectively. NLR and PLR values were compared using Levene's test between the groups.

\section{Statistical Analysis}

Descriptive statistical work-up was conducted for the study in order to give insight on general characteristics. Data on continuous variables were given as arithmetic mean, standard deviation and standard error. The study provides frequencies and percentages of qualitative (discrete) data. Levene's test was used to check whether data pertaining to continuous variables matched with normal distribution or not $(p \leq 0.05)$, and if ( $p>0.05)$, data were accepted to be in the range of normal distribution. As for inter-group comparisons of variables 


\begin{tabular}{|c|c|c|c|c|}
\hline Parameters & & NLR $<2.61$ & NLR > 2.61 & $\mathrm{p}$ value \\
\hline \multirow{3}{*}{ Tumor stage } & Low stage (T1+2) & $44(51.2 \%)$ & $42(48.8 \%)$ & \multirow{3}{*}{0.691} \\
\hline & & & & \\
\hline & High stage $(T 3+4)$ & $18(48.6 \%)$ & $19(51.4 \%)$ & \\
\hline \multirow{3}{*}{ Nuclear grade } & Low grade (grade $1+2$ ) & $48(51.6 \%)$ & $45(48.4 \%)$ & \multirow{3}{*}{0.674} \\
\hline & & & & \\
\hline & High grade (grade $3+4$ ) & $14(46.7 \%)$ & $16(53.3 \%)$ & \\
\hline
\end{tabular}

NLR: Neutrophil-to-lymphocyte ratio

\begin{tabular}{|c|c|c|c|c|}
\hline Parameters & & PLR $<128.75$ & PLR $>128.75$ & $p$ value \\
\hline \multirow[t]{2}{*}{ Tumor stage } & Low stage $(\mathrm{T} 1+2)$ & $48(55.8 \%)$ & $38(44.2 \%)$ & \multirow{2}{*}{0.067} \\
\hline & High stage $(\mathrm{T} 3+4)$ & $14(37.8 \%)$ & $23(62.2 \%)$ & \\
\hline \multirow{2}{*}{ Nuclear grade } & Low grade (grade $1+2$ ) & $51(54.8 \%)$ & $42(45.2 \%)$ & \multirow{2}{*}{0.083} \\
\hline & High grade (grade $3+4$ ) & $11(36.7 \%)$ & $19(63.3 \%)$ & \\
\hline
\end{tabular}

PLR: Platelet-to-lymphocyte ratio

indicated with measurement, a t-test was used for independent samples to study inter-group differences. A $p$ value of less than 0.05 was considered statistically significant. Calculations were made with available statistical software (IBM SPSS Statistics 21, SPSS Inc., an IBM Co., Somers, NY).

\section{Results}

The mean age of the 123 patients ( 64 female $-52.1 \%$ - and 59 male $-47.9 \%-)$ included in the study was $62.49 \pm 12.43(16-86)$ years. Fifty three $(43.1 \%)$ were symptomatic (diathesis, abdominal or flank pain, gross hematuria, palpable mass or paraneoplastic phenomena) and 70 (56.9\%) were incidentally diagnosed. Eighty five patients (69.1\%) underwent radical nephrectomy and 38 (30.9\%) only partial nephrectomy. Sixty one (49.6\%) patients were operated on the right side and $62(50.4 \%)$ on the left side. According to histological subtypes, 94 (76.4\%) patients had clear cell, 20 (16.3\%)-papillary, 7 (5.7\%)-chromophobe, 1 (0.8\%)-renal medullary carcinoma and $1(0.8 \%)$ had unclassified type RCC. Eighty six (69.9\%) patients were reported to have low-stage tumor (T1 or T2), whereas 37 (30.1\%) presented with high-stage tumor (T3 or T4). As for the Fuhrman nuclear grading, 93 patients $(75.6 \%)$ presented with low-grade tumors (grade 1 or 2 ) and 30 (24.4\%) with high-grade tumors (grade 3 or 4 ).

As regards to the classification per tumor stage, NLR and PLR were calculated as $3.83 \pm 3.22$ and $142.79 \pm 66.66$, respectively in the low-stage groups, while they were $4.43 \pm 5.29$ and $165.85 \pm 109.41$ in the high-stage group. According to the classification by the Fuhrman nuclear grading, NLR and PLR were calculated as $3.81 \pm 3.45$ and $146.63 \pm 87.36$, respectively in the low-grade groups whereas they were $4.61 \pm 5.387$ and $159.32 \pm 63.42$ in the high-grade group. Cut-off values calculated by receiver operating characteristic analysis for NLR and PLR were set as 2.61 and 128.75 , respectively. The patients were categorized according to the cut off values. NLR was found to be less than 2.61 in 44 of 86 low-stage patients (51.2\%), whereas it was above 2.61 in 19 of 37 high-stage tumor patients (51.4\%). PLR was above 128.75 in 38 (44.2\%) low-stage patients and 23 (62.2\%) high-stage patients. In addition, when the patients were classified according to be Fuhrman nuclear grading, in 48 out of 93 low-grade patients (51.6\%), NLR was found to be less than 2.61, whilst it was above 2.61 in 16 out of 30 high-grade patients (53.3\%). In 42 low-grade patients (45.2\%) and 19 (63.3\%) high-grade patients, PLR was above 128.75. Although there was a positive correlation between high NLR and PLR values and both high-tumor stage and high Fuhrman nuclear grade, this correlation was not statistically significant $(p>0.05)$. In conclusion, there was a statistically significant relationship of NLR value with pathological stage $(p=0.691)$ and Fuhrman nuclear grade $(p=0.674)$ (Tables 1 and 2$)$. Likewise, there was no statistically significant relationship of PLR value with pathological stage $(p=0.067)$ and Fuhrman nuclear grade of the tumor $(p=0.083)$.

\section{Discussion}

As is the case in our country, cancer has become a global public health issue. Although its progression may vary according to 
various factors including its histopathological nature, gender factors, life style, genetic factors, and geographical distribution, it is known as the second most common cause of mortality after cardiac diseases. It is estimated that 1.735 .350 new cancer cases will emerge in 2018 in the USA with 609.640 cancer-related mortalities (16).

Many prognostic factors have been defined for RCC including tumor stage, nuclear grade, type of histology, surgical margin, patient complaints, and performance status (17). One of the main goals of RCC studies is to introduce molecular-based prognostic factors into daily medical practice for use in survival prediction (18). This has obliged clinicians to find new ways of preoperative prediction of potential pathology and cancer progression status data for RCC. For healthcare expenditures to be effectively sustainable, cost analyses should be kept in consideration at all times. In this context, the medical community has long been in a search for using preoperative blood hemogram parameters for prediction of postoperative data.

Although sources of inflammation generally contain bacterial and viral infections, it is known that many factors, including tobacco use, obesity, fatty liver, alcohol, chemical exposure and radiation, indeed cause inflammation. Inflammation is classified in two stages as acute and chronic inflammation. Acute inflammation is the first stage of inflammation mediated by activation of the immune system. On the other hand, chronic inflammation may be considered a predisposing factor for the host into many chronic diseases including cancer.

It is known that inflammation plays a critical role in many stages of carcinogenesis including tumor development, progression and prognosis $(19,20)$. In particular, the tumor-infiltrating T-lymphocyte sub-types have a key role in cellular proliferation and metastases, in particular, in the tissue undergoing malignant transformation by playing a role in cellular viability and cytokine production (21). Another type of cells taking place in the inflammation and cancer association is the neutrophils. Neutrophils cause multiple and different types of cytokines. With such effects, neutrophils suppress the anti-tumor immunity system response resulting in tumor growth and progression by stimulating the angiogenesis (22). Although many links are yet to be made in the cancer and inflammation relationship, there are many studies discussing the use of hemogram parameters in prediction of tumor stage and grade and assessment of diseasespecific survival.

As regards to the analysis of studies looking into urogenital system cancers and NLR and PLR, Wei et al. (23) in a meta-analysis of 17 studies and 3159 cases reported a potential association between high NLR and poor clinical outcomes in urinary system cancers and suggested that NLR could be used as a significant biomarker of prognosis. In another meta-analysis, Hu et al. (24) assessed 15 studies and 3357 cases and concluded that high NLR was an indicator of poor prognosis in patients with RCC. As far as the studies looking into NLR and PLR together are concerned, in their study on 127 patients diagnosed with urothelia carcinoma and 162 control subjects, Luo et al. (25) stated that high NLR and PLR might be an independent determinant in cancer patients. In a similar study, Fankhauser et al. (26) reported that systemic inflammatory response markers might contribute to prediction of prognosis in metastatic testicular germ cell tumors.

As for the studies conducted in our country, a study by Kaynar et al. (27) on 291 patients with bladder tumor reported a positive correlation between tumor size and invasion and preoperative NLR. Similarly, Otunctemur et al. (28), in their series of 432 patients where they assessed surgical specimens obtained from RCC patients found a statistically significant relationship of NLR values with high tumor stage and nuclear grade. Nevertheless, in a study by Yıldırım et al. (29), the researchers could not find a significant association between preoperative NLR and tumor stage. In another study by Hamidi et al. (30) including 67 patients with testicular tumors, no statistically significant result was reported between NLR and disease-specific survival. Likewise, Bolat et al. (31) concluded that preoperative NLR was not a useful marker for predicting prognosis in germ cell testicular tumor patients.

\section{Study Limitations}

Although it may be considered a large-scale study, its retrospective design was a limitation.

\section{Conclusion}

Although not statistically significant, a positive correlation was observed between high tumor stage and high PLR and NLR values $(p>0.05)$. Similarly, a positive correlation was observed between high Fuhrman nuclear grade and high PLR and NLR values, but this association failed to reach the level of statistical significance $(p>0.05)$. Our study could not demonstrate a statistically significant correlation between PLR and NLR values and RCC tumor stage and Fuhrman nuclear grade, however, multi-center, prospective and large-scale studies are warranted.

\section{Ethics}

Ethics Committee Approval: Retrospective study.

Informed Consent: Retrospective study.

Peer-review: Internally peer-reviewed.

\section{Authorship Contributions}

Surgical and Medical Practices: E.K., D.A., B.P., S.C., Concept: E.K., D.A., B.P., S.C., V.Ü., I.E., Design: E.K., D.A., B.P., Ş.K., V.Ü., I.E., Data Collection or Processing: D.A., S.C., B.P., Analysis or Interpretation: E.K., D.A., V.Ü., I.E., Literature Search: E.K., S..K., Writing: E.K. 
Conflict of Interest: No conflict of interest was declared by the authors.

Financial Disclosure: The authors declared that this study received no financial support.

\section{References}

1. Jemal A, Siegel R, Ward E Murray T, Xu J, Smigal C, Thun MJ. Cancer statisitcs 2006. CA Cancer J Clin 2006;56:106-130.

2. Cheng L, Gregory TM. Neoplasms of the kidney. In: Urologic Surgical Pathology. Mosby Elsevier Indianapolis. 2nd ed. 2008, pp 82-112.

3. Landis SH, Murray T, Bolden S, Wingo PA. Cancer statistics, 1999. CA Cancer J Clin 1999;49:8-31.

4. Ljungberg B, Hanbury DC, Kuczyk MA, Merseburger AS, Mulders PF, Patard JJ, Sinescu IC; European Association of Urology Guideline Group for renal cell carcinoma. Eur Urol 2007;51:1502-1510.

5. Ferlay J, Soerjomataram I, Dikshit R, Eser S, Mathers C, Rebelo M, Parkin DM, Forman D, Bray F. Cancer incidence and mortality worldwide: sources, methods and major patterns in Globocan 2012. Int J Cancer 2015;136:359386.

6. Chow WH, Devesa SS, Warren JL, Fraumeni JF Jr. Rising incidence of renal cell cancer in the United States. JAMA 1999;281:1628-1631.

7. Xing $\mathrm{T}, \mathrm{He} \mathrm{H}$. Epigenomics of clear cell renal cell carcinoma: mechanisms and potential use in molecular pathology. Chin J Cancer Res 2016;28:80-91.

8. Pharoah PD, Dunning AM, Ponder BA, Easton DF. Association studies for finding cancer-susceptibility genetic variants. Nat Rev Cancer 2004;4:850860.

9. Coussens LM, Werb Z. Inflammation and cancer. Nature 2002;420:860-867.

10. MacDonald N. Cancer cachexia and targeting chronic inflammation: a unified approach to cancer treatment and palliative/supportive care. J Support Oncol 2007;5:157-162.

11. Gabay C, Kushner I. Acute-phase proteins and other systemic responses to inflammation. N Engl J Med 1999;340:448-454.

12. Roxburgh CS, McMillan DC. Role of systemic inflammatory response in predicting survival in patients with primary operable cancer. Future Oncol 2010:6:149-163.

13. Sobin $L H$, Gospodariwicz M, Wittekind C. TNM classification of malignant tumors. UICC International Union Against Cancer, 7th ed. Wiley-Blackwell, 2009.

14. Fuhrman SA, Lasky LC, Limas C. Prognostic significance of morphologic parameters in renal cell carcinoma. Am J Surg Pathol 1982;6:655-663.

15. Lopez-Beltran A, Scarpelli M, Montironi R, Kirkali Z. 2004 WHO classification of the renal tumors of the adults. Eur Urol 2006;49:798-805.
16. Siegel RL, Miller KD, Jemal A. Cancer statistics, 2018. CA Cancer J Clin 2018:68:7-30.

17. Srigley JR, Hutter RV, Gelb AB, Henson DE, Kenney G, King BF, Raziuddin S, Pisansky TM. Current prognostic factors--renal cell carcinoma: Workgroup No. 4. Union Internationale Contre le Cancer (UICC) and the American Joint Committee on Cancer (AJCC). Cancer 1997;80:994-996.

18. Ficara V, Galfano A, Novara G, lafrate M, Brunelli M, Secco S, Cavalleri S, Martignoni $G$, Artibani W. Risk stratification and prognostification of renal cell carcinoma. Worl J Urol 2008;26:115-125.

19. Mantovani A, Allavena P, Sica A, Balkwill F. Cancer-related inflammation. Nature 2008:454:436-444.

20. Reuter S, Gupta SC, Chaturvedi MM, Aggarwal BB. Oxidative stress, inflammation, and cancer: how are they linked? Free Radic Biol Med 2010;49:1603-1616.

21. Eerola AK, Soini $Y$, Paakko P. A high number of tumor-infiltrating lymphocytes are associated with a small tumor size, low tumor stage and a favorable prognosis in operated small cell lung carcinoma. Clin Cancer Res 2006;6:1875-1881.

22. Grivennikov SI, Greten FR, Karin M. Immunity, inflammation, and cancer Cell 2010;140:883-899.

23. Wei Y, Jiang YZ, Qian WH. Prognostic role of NLR in urinary system cancers: a meta-analysis. PLoS One 2014;9:e92079

24. Hu K, Lou L, Ye J, Zhang S. Prognostic role of the neutrophil-lymphocyte ratio in renal cell carcinoma: a meta-analysis. BMJ Open 2015;5:e06404.

25. Luo Y, Shi X, Li W, Mo L, Yang Z, Li X, Qin L, Mo W. Evaluation of the clinical value of hematological parameters in patients with urothelial carcinoma of the bladder. Medicine (Baltimore) 2018;14:e0351

26. Fankhauser CD, Sander S, Roth L, Gross O, Eberli D, Sulser T, Seifert B, Beyer J, Hermanns T. Systemic inflammatory markers have independent prognostic value in patients with metastatic testicular germ cell tumours undergoing first-line chemotherapy. Br J Cancer 2018;118:825-830.

27. Kaynar M, Yıldırım ME, Badem H, Caviş M, Tekinarslan E, Istanbulluoğlu MO, Karataş ÖF, Çimentepe E. Bladder cancer invasion predictability based on preoperative neutrophil-lymphocyte ratio. Tumour Biol 2014;35:66016605.

28. Otunctemur A, Dursun M, Besiroglu H, Ozer K, Horsanali O, Ozbek E. Clinical Significance of Preoperative Neutrophil to Lymphocyte Ratio in Renal Cell Carcinoma. Int Braz J Urol 2016;42:678-684.

29. Yıldırım ME, Badem H, Karatas ÖF, Çimentepe E, Ünal D. Preoperatif Nötrofil/ Lenfosit Oranının Testis Tümörlerinin Evresinin Tespitindeki Prediktif Değeri. Turgut Özal Tıp Mer Derg 2013;20:243-245.

30. Hamidi N, Süer E, Gökçe Mi. Bedük Y. Testis Tümörlü Hastalarda Ameliyat Öncesi Bakılan Serum Nötrofil-Lenfosit Oranı'nın Hastalığa Özgü Sağ kalım Üzerine Etkisi. Van Tıp Derg 2017;24:106-109.

31. Bolat D, Aydoğdu Ö, Polat S, Yarımoğlu S, Bozkurt iH, Yonguç T, Şen V. Predictive value of preoperative neutrophil-to-lymphocyte ratio on the prognosis of germ cell testicular tumors. Turk J Urol 2017;43:55-61. 